\title{
Ultrasound-Guided Transversus Abdominis Plane (TAP) Block for Chronic Post-Operative Surgical Pain: Review of 20 Cases
}

\author{
USAMA E. GHIEDA, M.D.* and ABDULLA M. HUSSEIN, M.D.** \\ The Department of Radiology, Faculty of Medicine, Tanta University* and National Liver Institute, Menofeya University**, \\ Egypt
}

\begin{abstract}
Background: Post-operative surgical pain of at least 2month duration in absence of clear causes was defined as Chronic Post-operative Surgical Pain syndrome (CPSP). Transversus Abdominis Plane (TAP) block is a new implemented regional anaesthetic technique included in the analgesic regimen for many abdominal surgeries to reduce immediate post-operative pain and opioid requirements.

Aim of Study: To assess the feasibility and efficacy of US guided TAP block in the management of chronic post-operative surgical pain.

Patients and Methods: US-guided TAB block done for 20 patients complaining of chronic lower abdominal pain around 3-months to one-year duration after surgical operation with injection of $20 \mathrm{ml}$ of bupivacaine $0.25 \%$ and $2 \mathrm{ml}$ of methyl prednisolone $(40 \mathrm{mg} / \mathrm{ml})$. Unilateral injection done for 12 patients \& bilateral injections done for 8 patients. Second injection done for 6 patients after 3 months (three unilateral $\&$ three bilateral). Patient's pain intensity was assessed by Visual Analogue Score (VAS) before procedure \& during follow-up visits for the next six months.
\end{abstract}

Results: Three months after US-guided TAP block; 5 patients with mild degree of pain \& 2 out of 10 patients with moderate degree of pain became completely pain free, while other 13 patients acquired relative improvement ( 5 patients with mild degree of pain and 8 patients with moderate degree of pain). Six months after US-guided TAP block; 6 patients (accepted second injection) improved with mild degree of pain while other 2 patients showed little improvement with still moderate degree of pain.

Conclusion: Ultrasound guided TAP block is safe and effective method in management of chronic post-operative surgical pain.

Key Words: Ultrasound-guided transversus abdominis plane block (US-guided TAP) - Chronic post-operative surgical pain (CPSP).

Correspondence to: Dr. Usama E. Ghieda, E-Mail: usama_ghieda@yahoo.com

\section{Introduction}

POST-OPERATIVE surgical pain of at least 2month duration in absence of clear causes was defined as Chronic Post-operative Surgical Pain syndrome (CPSP) [1]. Many pre-, intra-, and postoperative risk factors have been included in the development of CPSP, not only nerve damage during surgery [2]. Various methods have been described in its management, like Non-Steroidal Anti-Inflammatory Drugs (NSAID), nerve and plane block as well as psychiatric counselling [3]

Transversus Abdominis Plane (TAP) block is a new implemented regional anaesthetic technique included in the analgesic regimen for many abdominal surgeries to reduce immediate post-operative pain and opioid requirements [4].

As thoracolumbar nerves originating from the T6 to L1 spinal roots run through neurofascial plane between the internal oblique and the transverses abdominis muscles and supply sensory nerves to the anterolateral abdominal wall [5]. Local anaesthetic drugs injected into this plane block the neural afferents with subsequent analgesia to the anterolateral abdominal wall [6] .

Dexamethasone was used as a supplement to improves the quality and duration of the local anaesthetics through several ways including attenuating the release of inflammatory mediators, reducing ectopic neuronal discharge, and inhibiting potassium channel-mediated discharge of nociceptive C-fibres [7-9].

\footnotetext{
List of Abbreviations:

US : Ultrasound.

TAP : Transversus Abdominis Plane.

CPSP : Chronic Post-operative Surgical Pain.

VAS : Visual Analogue Score.
} 
Ultrasound guided techniques for peripheral nerve block are now considered the gold standard to improve its success rate [10]. For most TAP block, linear probe is usually adequate for most cases, yet convex probe may be needed in markedly obese patients [11-13]

The aim of this study is to assess the feasibility and efficacy of US guided TAP block in the management of chronic post-operative surgical pain.

\section{Patients and Methods}

Our Institutional Review Board approved this prospective study. An informed consent was obtained from all patients. The study was done on 20 patients ( 8 male \& 12 female) with age ranged from 28 to 54 years (mean age 43.5 years \pm 7.8 ) diagnosed as Chronic Post-operative Surgical Pain syndrome (CPSP) from January 2018 to December 2018.

All patients were complaining of lower abdominal pain around 3-months to one-year duration after surgical operation.

Inclusion criteria include lower abdominal dull aching pain not relieved with routine analgesics, insidious in onset, progressive in nature and present throughout the day. There were no associated symptoms such as abdominal distension, vomiting, constipation, or fever. There was no similar illness before surgical procedures.

Exclusion criteria were a history of drug allergy or local anaesthetic toxicity, contraindications to regional anaesthesia (bleeding diathesis \& infection at the site of block) as well as patient with known abdominal pathology.

Clinical examinations for all patient were normal. Examination of the surgical scars showed no significant abnormality. All patients had already been subjected to routine blood investigations $\&$ abdominal ultrasound which were normal. Contrast enhanced CT abdomen examination were done for 10 patients $\&$ another 3 patients undergone diagnostic laparoscopy which were all unremarkable.

\section{Technique:}

US-guided TAP blocks were performed by using Siemens Acuson X 600 ultrasound machine with a linear transducer $(5-11 \mathrm{MHz})$.

The procedure was performed using rigorous aseptic technique (gown, gloves \& facemasks). The transducer was inserted into sterile bag and sterile gel was applied to it. The patient lie in supine position \& block area was sterilized with $10 \%$ povidone.

The probe was placed transversely at the mid axillary line between the costal margin and iliac crest. Under US guidance; skin, subcutaneous tissues \& the three layers of muscles (external oblique, internal oblique, transversus abdominis) were identified Fig. (1) and the depth of TAP was measured.

A 21-gauge needle was introduced away from the transducer from medial to lateral in plane of the ultrasound beam and advanced until it reaches the fascial plane between the internal oblique and transversus abdominis muscles with its tip in mid axillary line Fig. (2) then $2 \mathrm{ml}$ of saline was injected to confirm correct needle position within Transversus Abdominis Plane (TAP) appeared as a hypoechoic space Fig. (3). Careful aspiration done to avoid intravascular injections, after which $20 \mathrm{ml}$ of bupivacaine $0.25 \%$ and $2 \mathrm{ml}$ of methyl prednisolone $(40 \mathrm{mg} / \mathrm{ml})$ were injected Fig. (4). No complications occurred throughout the injection process in all patients.

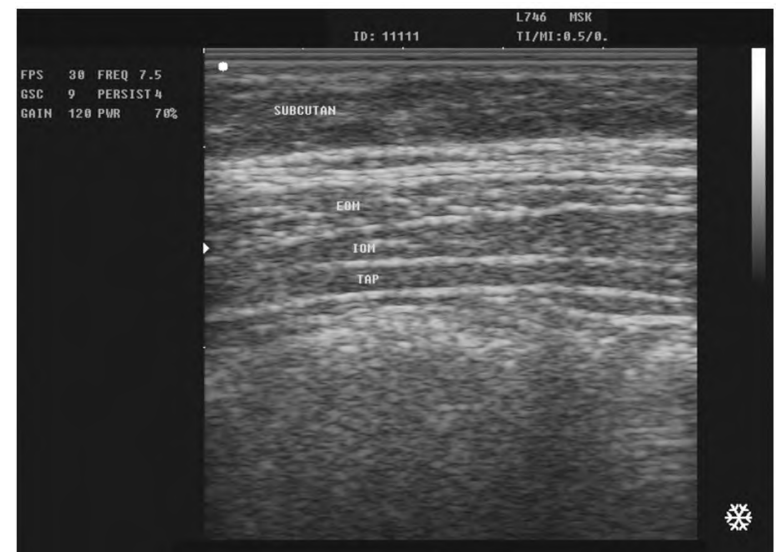

Fig. (1): US transverse scan in mid-axillary line between costal margin \& iliac crest shows the three muscle layers with TAP between internal oblique \& transversus abdominis muscles.

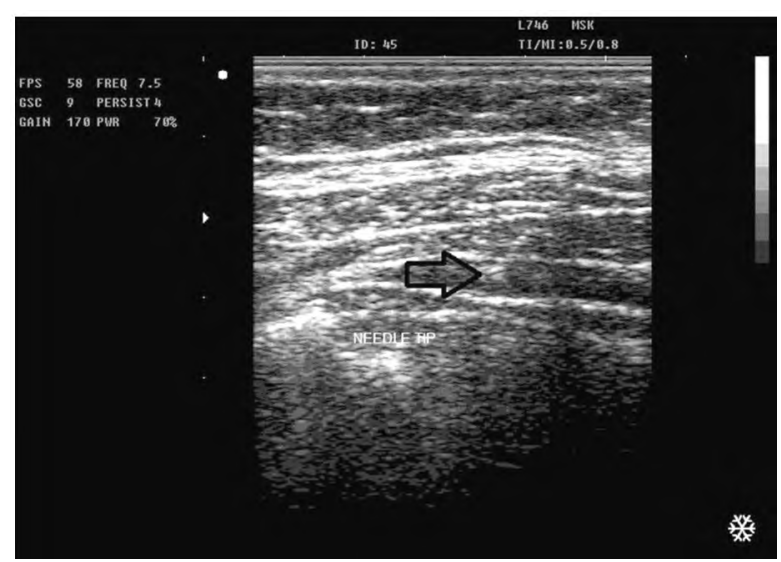

Fig. (2): The tip of needle is seen within the TAP in mid axillary line (arrow). 


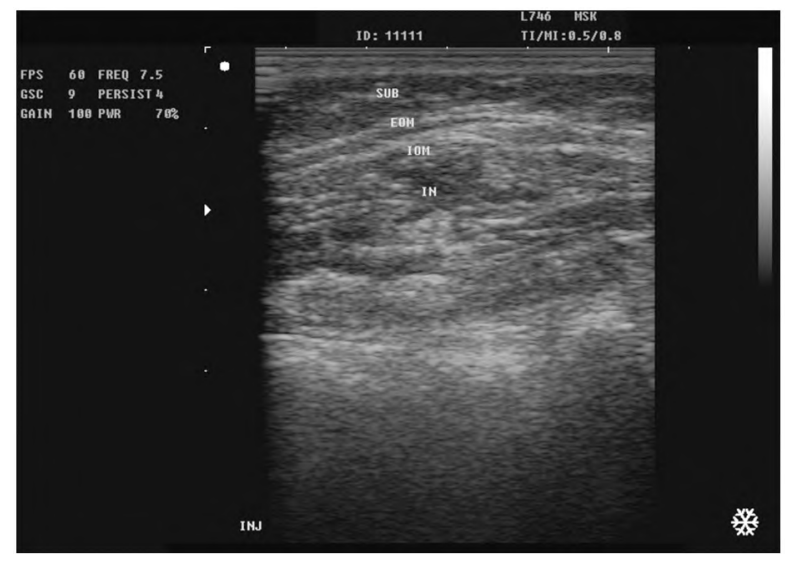

Fig. (3): Injected saline appeared as anaechoic space within TAP.

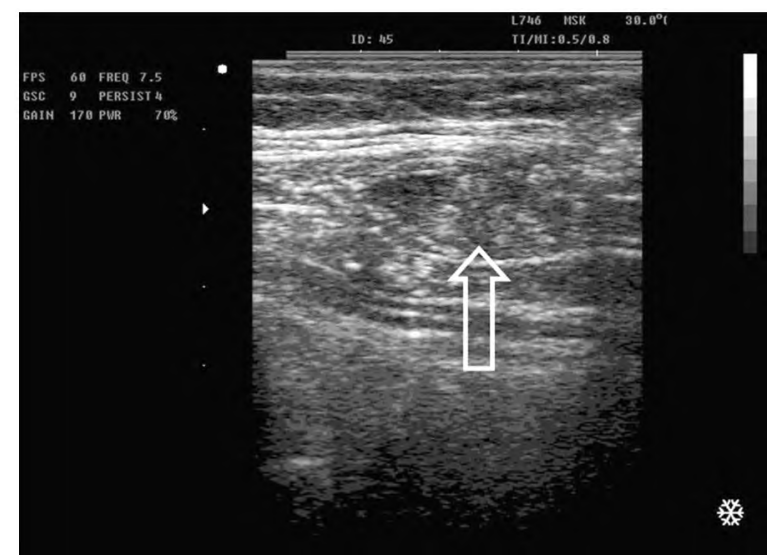

Fig. (4): The injected material is seen within the TAP (arrow).

Unilateral injection done for 12 patients; 9 injections on right side \& 3 injection on left side, while bilateral injections done in the remaining 8 patients.

After local anaesthetic injection, patients were closely observing, no signs of toxicity were noted in any of them.

Eight patients were asked for second injection after 3 months with 6 patient accepted (three unilateral \& three bilateral) while other two patients refused.

\section{Evaluation of outcome:}

Patient's pain intensity was assessed by Visual Analogue Score (VAS) before procedure \& during follow-up visits for the next six months with score 0 indicating no pain, score 1-3 indicating mild pain, score 4-6 indicating moderate pain \& score 7-10 indicating severe pain. Data were analysed using Minitab version 16 (Minitab Inc. USA).

\section{Results}

Twenty patients ( 8 male $\& 12$ female) with age ranged from 28 to 54 years (mean age 43.5 years \pm 7.8 ) were included in the current study, presented with chronic lower abdominal pain of variable duration 3-months to one year after surgical procedures, not responding to routine analgesics and diagnosed as Chronic Post-operative Surgical Pain (CPSP) syndrome. US guided TAP block was done for all patients with unilateral injection in 12 patients \& bilateral injections in 8 patients. Repeated injection was done after 3 months for 6 patients (3 bilateral \& 3 unilateral) as shown on (Table 1).

Table (1): Type of operation, number of patient, side of US guided TAP block and number of injection in 20 patients.

\begin{tabular}{|c|c|c|c|c|c|}
\hline \multirow[t]{2}{*}{ Type of operation } & \multirow[t]{2}{*}{$\begin{array}{l}\text { No. of } \\
\text { patient }\end{array}$} & \multicolumn{2}{|c|}{$\begin{array}{l}\text { Side of US } \\
\text { guided } \\
\text { TAP block }\end{array}$} & \multicolumn{2}{|c|}{$\begin{array}{c}\text { No } \\
\text { of } \\
\text { injection }\end{array}$} \\
\hline & & Right & Left & Single & Twice \\
\hline Open appendicectomy & 6 & 6 & & 5 & 1 \\
\hline Inguinal hernia repair & 6 & 3 & 3 & 4 & 2 \\
\hline Caesarean section & 5 & 5 & 5 & 3 & 2 \\
\hline Subtotal hysterectomy & 3 & 3 & 3 & 2 & 1 \\
\hline
\end{tabular}

Five patients presented at base line with mild degree of pain according to VAS, 10 patients with moderate degree and 5 patients with severe degree. Three months after TAP block; 5 patients with mild degree of pain as well as 2 out of 10 patients with moderate degree of pain became completely pain free (VAS 0), while other 13 patients acquired relative improvement (5 patients with mild degree of pain and 8 patients with moderate degree of pain).

Eight patients with moderate degree of pain 3 months after TAP block were asked for second injection; 6 patients accepted while other two patients refused. During further follow-up after 6 months; 6 patients (accepted second injection) improved with mild degree of pain while other 2 patients showed little improvement with still moderate degree of pain as shown on (Table 2).

Table (2): VAS \& number of patients at baseline, 3 months \& 6 months from TAP block.

\begin{tabular}{lccccc}
\hline \multicolumn{2}{c}{ VAS at baseline } & \multicolumn{2}{c}{$\begin{array}{c}\text { VAS at 3 months } \\
\text { from TAP block }\end{array}$} & \multicolumn{2}{c}{$\begin{array}{c}\text { VAS at 6 months } \\
\text { from TAP block* }\end{array}$} \\
\hline $\begin{array}{l}\text { Score } \\
\text { Mean } \pm \text { SD) }\end{array}$ & $\begin{array}{c}\text { No. of } \\
\text { cases }\end{array}$ & $\begin{array}{c}\text { Score } \\
(\text { Mean } \pm \text { SD) }\end{array}$ & $\begin{array}{c}\text { No. of } \\
\text { cases }\end{array}$ & $\begin{array}{c}\text { Score } \\
\text { (Mean } \pm \text { SD) }\end{array}$ & $\begin{array}{c}\text { No. of } \\
\text { cases }\end{array}$ \\
\hline $\begin{array}{l}\text { Mild } \\
(2.6 \pm 0.48)\end{array}$ & 5 & No & 7 & No & 12 \\
$\begin{array}{l}\text { Moderate } \\
(5.2 \pm 0.74)\end{array}$ & 10 & $\begin{array}{l}\text { Mild } \\
(2.2 \pm 0.4)\end{array}$ & 5 & $\begin{array}{l}\text { Mild } \\
(2.5 \pm 0.5)\end{array}$ & 6 \\
$\begin{array}{l}\text { Severe } \\
(7.8 \pm 0.74)\end{array}$ & 5 & $\begin{array}{l}\text { Moderate } \\
(5.25 \pm 0.96)\end{array}$ & 8 & $\begin{array}{l}\text { Moderate } \\
(5.0 \pm 0.0)\end{array}$ & 2 \\
\hline
\end{tabular}

*: Six patients done second injection after 3 months. 


\section{Discussion}

Chronic post-operative pain is a special entity within the domain of chronic pain, which could occur after any surgical procedures. The cause of such pain is usually multifactorial $\&$ often not possible to point to a distinct reason in every patient [14] . Improper control of such pain can be associated with higher rate of complications, longer analgesic usage, higher health care costs, functional impairment, and lower quality of life [15].

Many studies aimed to characterize management and treatment strategies for all post-operative chronic pain conditions: However, it is likely that chronic pain resulting from different procedures needs to have their own diagnostic algorithm and specific treatment [16].

Werner MU [17] suggested range of interventions to manage persistent postsurgical inguinal pain including; watchful waiting, pharmacological treatments, local anaesthetic blocks, sensory stimulation or ablation of nerves, and surgery (mesh removal, reoperation for recurrence, and neurectomy).

TAP block have proved as a safe technique with few reported complications like intra-peritoneal injection, bowel hematoma and transient femoral nerve palsy with the most serious reported complication was a case report of intrahepatic injection $[18,19]$. Local anaesthetic toxicity (tinnitus, perioral numbness, metallic taste in mouth, slurring of speech and mental status changes) was also reported secondary to the large volumes required to perform adequate block especially with bilateral injection [19]. With US guided technique, TAP blocks become easier and safer. In our study, no complication recorded from US guided TAP block in all patients.

TAP is widely used as therapeutic adjuncts for analgesia after variety of abdominal surgeries, such as open appendicectomy, caesarean section, hysterectomy, cholecystectomy, colectomy, prostatectomy, and hernia repair to reduce immediate postoperative pain and opioid requirements [4,20-28]

Several studies reported significant effect of TAP block during surgery in preventing the development of chronic pain after inguinal hernioplasty $[29,30]$

Parthasarathy \& Naveenkumar [31] reported a case study of successful use of TAP block to manage chronic severe pain at appendicectomy scar site of six-months duration. No more available studies about the application of TAP block in management of chronic post-operative surgical pain.

In our study US guided TAP block with combined injection of local anaesthetic agent $(20 \mathrm{ml}$ of bupivacaine $0.25 \%$ ) and $2 \mathrm{ml}$ of methyl prednisolone $(40 \mathrm{mg} / \mathrm{ml})$ was successful in the management of chronic post-operative surgical pain in 6 patients after open appendicectomy, 6 patients after inguinal hernia repair, 5 patients after caesarean section $\&$ 3 patients after subtotal hysterectomy with high successful rate in patients with mild \& moderate degree of pain. Patients with severe degree of pain needed repeated injection after 3 months.

Though our study identified areas for future research, it had certain limitations as the sample size of our trial was insufficient to assess the efficacy of TAP block as regard to different surgical procedures. Also, our patients were not followedup for long term.

\section{Conclusion:}

Ultrasound guided TAP block is safe and effective method in management of chronic post operative surgical pain.

\section{Conflict of interest:}

We have no conflict of interest to declare.

\section{References}

1- MACRE W.A.: Chronic pain after surgery. Br. J. Anaesth., 87: 88-98, 2001.

2- PERKINS F.M. and KEHLET H.: Chronic pain as an outcome of surgery. A review of predictive factors. Anaesthesiology, Vol. 93 (pg. 1123-33), 2000.

3- MARGENTHALER J.A., LONGO W.E., VIRGO K.S., et al.: Risk Factors for Adverse Outcomes After the Surgical Treatment of Appendicitis in Adults. Annals of Surgery, 238 (1): 59-66, 2003.

4- NIRAJ G., SEARLE A., MATHEWS M., MISRA V., BABAN M., KIANI S. and WONG M.: Analgesic efficacy of ultrasound-guided transversus abdominis plane block in patients undergoing open appendicectomy. Br. $\mathbf{J}$. Anaesth., 103: 601-5, 2009.

5- ROZEN W.M., TRAN T.M.N., ASHTON M.W., BARRINGTON M.J., IVANUSIC J.J. and TAYLOR G.I.: Refining the course of the thoracolumbar nerves: A new understanding of the innervation of the anterior abdominal wall. Clinical Anatomy, Vol. 21, No.4, pp. 325-33, 2008.

6- TSAI H.C., YOSHIDA T., CHUANG T.U., YANG S.F., CHANG C.C., YAO H.U., TAI U.T., LIN J. and CHEN K.Y.: Transversus Abdominis Plane Block: An Updated Review of Anatomy and Techniques. Bio Med Research International. Volume, Article ID 8284363, 12 pages. https://doi.org/10.1155/2017/8284363, 2017.

7- ATTARDI B., TAKIMOTO K., GEALY R., SEVERNS C. and LEVITAN E.S.: Glucocorticoid induced up- 
regulation of a pituitary $\mathrm{K}+$ channel mRNA in vitro and in vivo. Receptors Channels, 1: 287-93, 1993.

8- EKER H.E., COK O.Y., ARIBOGAN A. and ARSLAN G.: Management of neuropathic pain with methylprednisolone at the site of nerve injury. Pain Med., 13: 443$51,2012$.

9- JOHANSSON A., HAO J. and SJOLUND B.: Local corticosteroid application blocks transmission in normal nociceptive C-fibres. Acta Anaesthesiol. Scand., 34: 3358, 1990.

10- HOPKINS P.M.: Ultrasound guidance as a gold standard in regional anaesthesia. British Journal of Anaesthesia, Vol. 98, No. 3, pp. 299-301, 2007.

11- HEBBARD P.D., BARRINGTON M.J. and VASEY C.: Ultrasound guided continuous oblique subcostal transversus abdominis plane blockade: Description of anatomy and clinical technique. Regional Anesthesia and Pain Medicine, Vol. 35, No. 5, pp. 436-41, 2010.

12- UESHIMA H., KUBO K. and SAKAMOTOETAL S.: A case of the transversus abdominis plane block in a super obese patient using a convex probe. Masui (The Japanese Journal of Anesthesiology), Vol. 62, No. 4, pp. 439-41, 2013.

13- WASSEF M., LEE D.Y. and LEVINEETAL J.L.: Feasibility and analgesic efficacy of the transversus abdominis plane block after single port laparoscopy in patients having bariatric surgery. Journal of Pain Research, Vol. 6, pp. 837-41, 2013.

14- ANDRESEN K. and ROSENBERG J.: Management of chronic pain after hernia repair. Journal of Pain Research, 11: 675-81 downloaded from https://www.dovepress.com/ by $41.36 .151 .247,2018$.

15-GAN T.J.: Poorly controlled postoperative pain: Prevalence, consequences, and prevention. J. Pain Res., 10: 2287-98, 2017.

16- WYLDE V., DENNIS J., BESWICK A.D., et al.: Systematic review of management of chronic pain after surgery. Br. J. Surg., 104 (10): 1293-306, 2017.

17- WERNER M.U.: Management of persistent postsurgical inguinal pain. Langenbecks Arch. Surg., 399 (5): 559-69, 2014.

18- FAROOQ M. and CAREY M.: A Case of Liver Trauma with a Blunt Regional Anesthesia Needle While Performing Transversus Abdominis Plane Block Regional Anesthesia and Pain Medicine, 33: 274-5, 2008.

19- MUKHTAR K.: Transversus Abdominis Plane (TAP) block. The journal of the New York school of regional anaesthesia, 12: 28-33, 2009.

20- RAFI A.N.: Abdominal field block: A new approach via the lumbar triangle. Anaesthesia, Vol. 56, No. 10, pp. 1024-6, 2001.

21- NIRAJ G., SEARLE A., MATHEWS M., et al.: Analgesic efficacy of ultrasound-guided transversus abdominis plane block in patients undergoing open appendicectomy. $\mathrm{Br}$. J. Anaesth., 103: 601-5, 2009.

22- BROGI E., KAZAN R., CYR S., GIUNTA F. and HEMMERLING T.M.: Transversus abdominal plane block for postoperative analgesia: A systematic review and metaanalysis of randomized controlled trials. Canadian Journal of Anaesthesia, Vol. 63, No. 10, pp. 1184-96, 2016.

23- CHAMPANERIA R., SHAH L., GEOGHEGAN J., GUPTA J.K. and DANIELS J.P.: Analgesic effectiveness of transversus abdominis plane blocks after hysterectomy: A meta-analysis. European Journal of Obstetrics \& Gynecology and Reproductive Biology, Vol. 166, No. 1, pp. 19, 2013.

24- ELKASSABANY N., AHMED M., MALKOWICZ S.B., HEITJAN D.F., ISSERMAN J.A. and OCHROCH E.A.: Comparison between the analgesic efficacy of transversus abdominis plane (TAP) block and placebo in open retropubic radical prostatectomy: A prospective, randomized, double-blinded study. Journal of Clinical Anaesthesia, Vol. 25, No. 6, pp. 459-65, 2013.

25- K. PENG K., JI F.H., LIU H.Y. and WU S.R.: Ultrasound Guided Transversus Abdominis Plane Block for Analgesia in Laparoscopic Cholecystectomy: A Systematic Review and Meta-Analysis. Medical Principles and Practice, Vol. 25, No. 3, pp. 237-46, 2016.

26- MISHRIKY B.M., GEORGE R.B. and HABIB A.S.: Transversus abdominis plane block for analgesia after Caesarean delivery: A systematic review and metaanalysis. Canadian Journal of Anaesthesia, Vol. 59, No. 8, pp. 766-78, 2012.

27- VENTHAM N.T., O'NEILL S., JOHNS N., BRADY R.R and FEARON K.C.H.: Evaluation of novel local anaesthetic wound infiltration techniques for post-operative pain following colorectal resection surgery: A metaanalysis. Diseases of the Colon \& Rectum, Vol. 57, No.2, pp. 237-50, 2014.

28- GAO T., ZHANG J.J., XI F.C., et al.: Evaluation of Transversus Abdominis Plane (TAP) block in hernia surgery. The Clinical Journal of Pain, Vol. 33, No. 4, pp. 369-75, 2017.

29- TOPAL A., SARGiN M., KILICASLAN A. and UZUN S.T.: The Effect of Transversus Abdominis Plane Block in Inguinal Hernioplasty on Chronic Pain. Eur. J. Gen. Med., 12 (4): 291-7, 2015.

30- OKUR O., TEKGUL Z.T. and ERKAN N.: Comparison of efficacy of transversus abdominis plane block and iliohypogastric/ilioinguinal nerve block for postoperative pain management in patients undergoing inguinal herniorrhaphy with spinal anaesthesia: A prospective randomized controlled open-label study [published online June 14]. J. Anesth., doi: 10.1007/s00540-017-2378-3, 2017.

31- PARTHASARATHY S. and NAVEENKUMAR G.: Management of Chronic Post-operative Surgical Pain (CPSP) following appendicectomy. Sri Lankan Journal of Anaesthesiology, 26 (1): 64-65, 2018. 


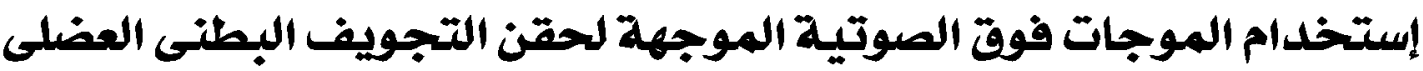

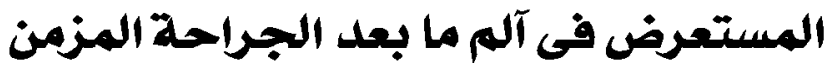

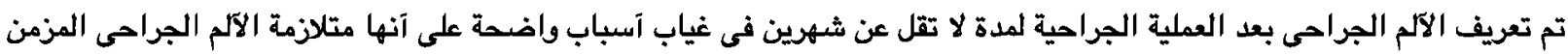

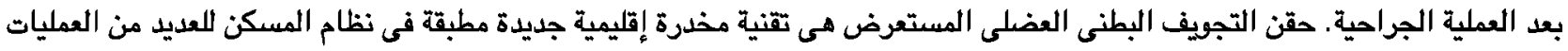
الجراحية فى البطن لتقليل الآلم الفورى بعد الجراحئ البراحة ومتطلبات الآفيونيات.

تهدف الدراسة إلى تقييم جلوى وفعالية إستخدام الموجات فوق الموتية الموجهه لدقن التجويف البطنى العضلى المستعرض فى إدارة الآلم الجراحى المزمن بعد العملية الجراحية.

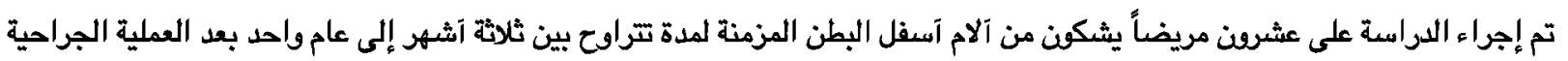

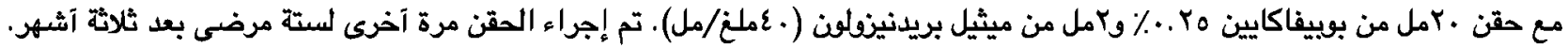

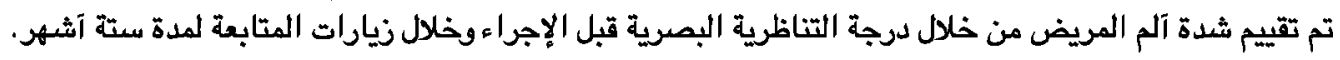

خلصت الدراسة إلى آن إستخدام الموجات فوق الصوتية الموجهة لحقن التجويف البطنى العضلى المستعرض هى طريقة آمنة وفعالة فى إدارة الآلم الجراحى المزمن بعد العملية الجراحية. 